Short report

\title{
Deletion of the AP1S2 gene in a child with psychomotor delay and hypotonia
}

\author{
Lucia Ballarati $^{\mathrm{a}, *}$, Anna Cereda ${ }^{\mathrm{b}}$, Rossella Caselli ${ }^{\mathrm{a}}$, Silvia Maitz $^{\mathrm{b}}$, Silvia Russo ${ }^{\mathrm{a}}$, Angelo Selicorni $^{\mathrm{b}}$, \\ Lidia Larizza $^{\mathrm{a}, \mathrm{c}}$, Daniela Giardino ${ }^{\mathrm{a}}$ \\ ${ }^{a}$ Laboratorio di Citogenetica Medica e Genetica Molecolare, IRCCS Istituto Auxologico Italiano, Milano, Italy \\ ${ }^{\mathrm{b}}$ Ambulatorio Genetica Clinica, Clinica Pediatrica, Università di Milano Bicocca, Fondazione MBBM, A.O. S. Gerardo, Monza, Italy \\ ${ }^{\mathrm{c}}$ Genetica Medica, Dipartimento di Medicina Chirurgia e Odontoiatria, Università di Milano, Polo H. S. Paolo, Milano, Italy
}

\section{A R T I C L E I N F O}

\section{Article history:}

Received 15 September 2011

Accepted 9 December 2011

Available online 17 December 2011

\section{Keywords:}

Xp22.2 deletion

Array-CGH

AP1S2

\begin{abstract}
A B S T R A C T
We identified a $495 \mathrm{~Kb}$ interstitial deletion of chromosome Xp22.2, centered on the AP1S2 gene, by means of oligonucleotide array comparative genomic hybridisation (array-CGH) in a child with marked hypotonia in the first months of life, psychomotor retardation, severely delayed walking and speech development, and unspecific dysmorphic facial features. The deletion was inherited from the healthy mother. Point mutations of the AP1S2 gene have been identified in patients with X-linked mental retardation (XLMR). The clinical features of our patient are quite similar to those reported in male patients carrying point mutations, thus suggesting that point mutations and deletions of the AP1S2 gene lead to a recognisable XLMR phenotype in males.
\end{abstract}

(c) 2011 Elsevier Masson SAS. All rights reserved.

\section{Introduction}

Mental retardation (MR) affects about $1-3 \%$ of the population. It is more common in males (an excess of about 30\%) [1] because of the high incidence of mutations in genes located on the $\mathrm{X}$ chromosome that together explain $10-12 \%$ of MR in males [2]. More than $80 \mathrm{X}$-linked mental retardation (XLMR) genes have so far been identified $[3,4]$. XLMR has been classified into syndromic and nonsyndromic forms, depending on whether the MR is associated with other clinical, radiological or metabolic features or not, but this subdivision appears unsatisfactory since many genes are involved in both forms [2,5].

The AP1S2 gene (OMIM ID: 300629), which maps to Xp22.2, has been proposed as a candidate for XLMR because it has been found to be mutated in seven unrelated XLMR families [6-8]. It encodes the $\sigma 1 \mathrm{~B}$ subunit of clathrin-associated adaptor protein complex 1 (AP1), which is involved in transporting proteins between the trans-Golgi network and endosomes and interacts with synaptic vescicle proteins, thus playing an important role in neurotransmitter release [9].

We describe a child with psychomotor retardation, severely delayed walking and speech development, marked hypotonia and unspecific dysmorphic facial features, who was found to

\footnotetext{
* Corresponding author. Lab Citogenetica Medica e Genetica Molecolare, IRCCS Istituto Auxologico Italiano, Via Zucchi 18, 20095 Cusano Milanino MI, Italy. Tel.: +3902 619112006; fax: +39 02619112464 .

E-mail address: l.ballarati@auxologico.it (L. Ballarati).
}

carry a cryptic interstitial $495 \mathrm{~Kb}$ deletion at Xp22.2, including the AP1S2 gene.

\section{Clinical report}

The patient is the only child of a healthy and unrelated 38-yearold father and 37-year-old mother, whose family histories are negative for genetic diseases. The results of prenatal ultrasonography were normal. The child was born by spontaneous vaginal delivery at a gestational age of 39 weeks; at birth, his weight was $3.450 \mathrm{~kg}$ (50th percentile), length $51 \mathrm{~cm}$ (50th percentile), occipitofrontal circumference (OFC) $34 \mathrm{~cm}$ (25th percentile), and APGAR scores 8 and 10 after respectively 1 and 5 min. No major medical problems were observed during the neonatal period except for poor sucking. Psychomotor delay and hypotonia became evident at the age of 4 months. The results of various clinical and instrumental examinations (echocardiography, ophthalmological screening, brain magnetic resonance imaging and computed tomography [CT], muscle CT, electroencephalography, evoked visual and acoustic potentials, electroretinography) were normal; electromyography and muscle biopsy revealed only slight and unspecific anomalies. The neurological follow-up confirmed the marked hypotonia and delayed achievement of the first psychomotor milestones (nuchal stability at 9 months, sitting alone at 12 months). The child showed also hyperreflexia, poor social interactions and stereotypies (repetitive hand movements).

He was referred to us at the age of 13 months, when his weight was $9.920 \mathrm{~kg}$ (10-25th percentile), height $81 \mathrm{~cm}$ (75th percentile) 


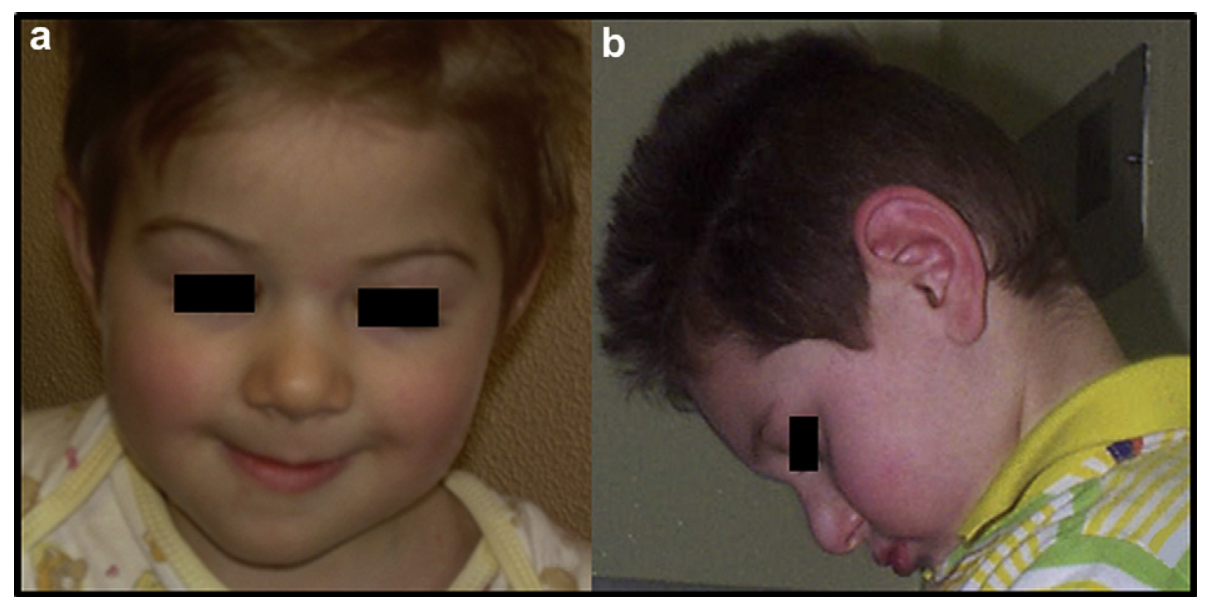

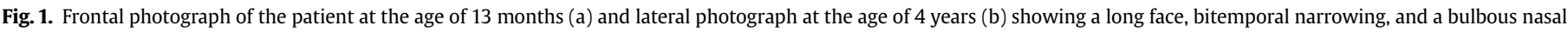
tip.

and OFC $45 \mathrm{~cm}$ (10th percentile). His dysmorphic facial features included a long face, bitemporal narrowing, deeply-set eyes, strabismus, up-slanting palpebral fissures, and a bulbous nasal tip (Fig. 1a).

The results of methylation test of the $15 q 11.2$ region, study of subtelomeric rearrangements, and molecular analysis of the UBE3A gene were normal.
He underwent his last follow-up evaluation at the age of 4 years, when his weight was $13.5 \mathrm{~kg}$ (3-10th percentile), height $107.5 \mathrm{~cm}$ (90th percentile) and OFC $48.5 \mathrm{~cm}$ (3rd percentile). A clinical examination did not show any change in his facial phenotype (Fig. 1b), and he was also affected by hypermetropia and constipation. The neuropsychiatric follow-up confirmed the psychomotor delay, with significantly delayed walking and speech

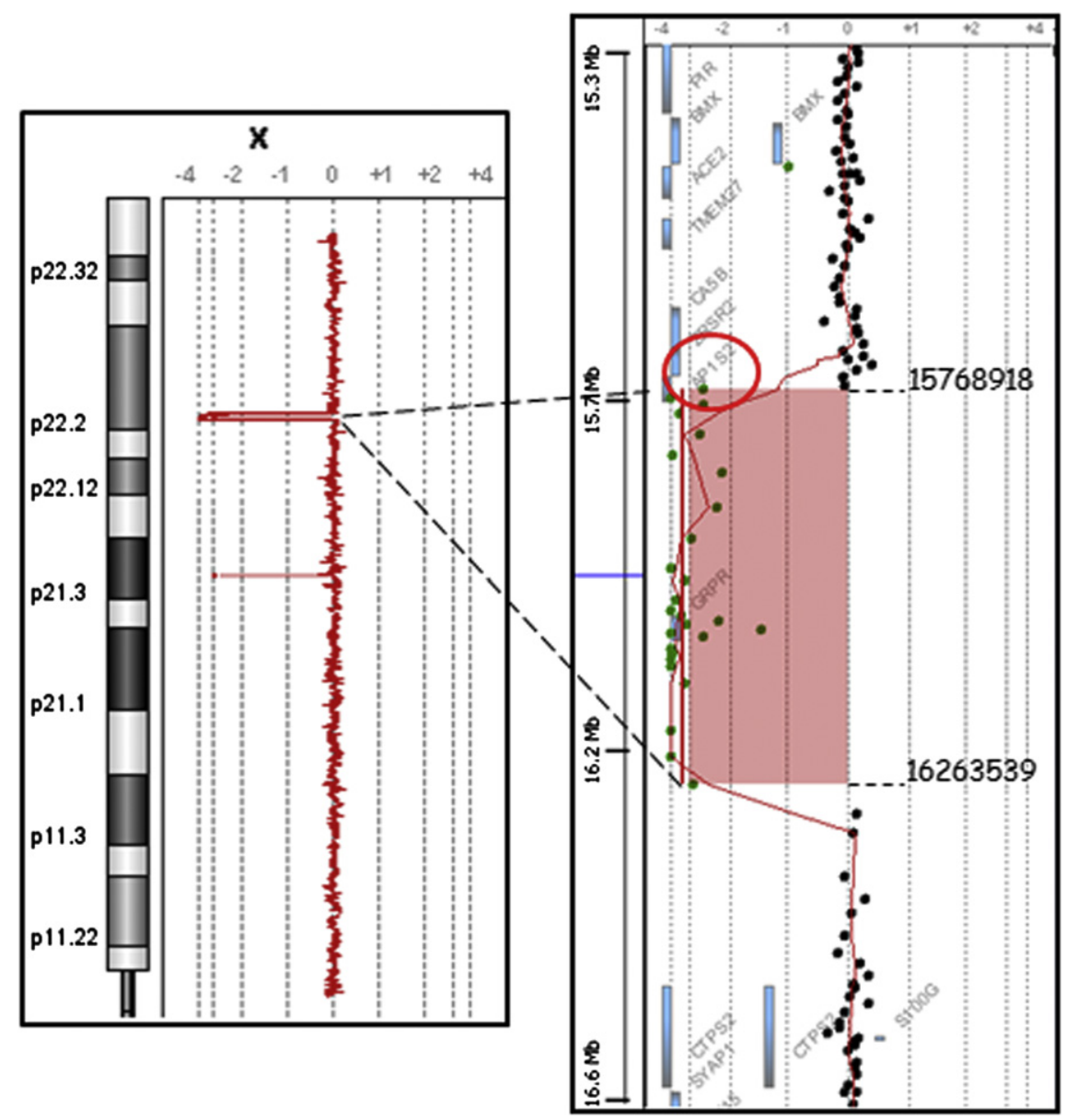

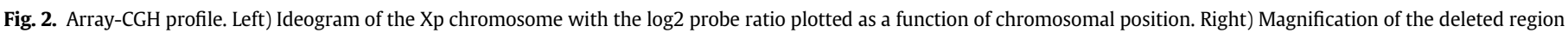
indicating the distal and proximal breakpoint positions and the included genes. 
development, and revealed a slow improvement in the hypotonia and social interactiveness.

\section{Material and methods}

Array-CGH of genomic DNA from the proband and his parents was performed using the Human Genome CGH Microarray kit 44K (Agilent, Santa Clara, CA) and, restricted to the proband, the Human Genome CGH Microarray kit 244A (Agilent). These platforms allow a genome-wide survey with an average resolution of respectively $\sim 130$ and $\sim 50 \mathrm{~Kb}$. The genomic DNAs were labelled and hybridised in accordance with the manufacturer's protocol, and the arrays were analysed using Agilent Scan Control (v A8.4.1), Feature Extraction software (v 10.7.1.1), and DNA Analytics software ( $v$ 4.0). The unbalanced region revealed by the analysis was analysed in silico using the March 2006 release of the UCSC Genome Browser (http://genome.ucsc.edu/) and the Database of Genomic Variants (http://projects.tcag.ca/variation).

The methylation status of the X chromosome in the patient's mother was assessed using the Humara Androgen Receptor gene methylation assay as previously described [10]. The triplet repeats were separated by means of capillary electrophoresis and analysed using an ABI PRISM 3005.

\section{Results}

Array-CGH using the Human Genome CGH Microarray kit 44K revealed the presence of an interstitial Xp22.2 deletion (not shown), which was confirmed and more precisely defined by means of the higher-resolution $244 \mathrm{~K}$ platform. The breakpoints of the $\sim 495 \mathrm{~Kb}$ deletion are located proximally between 16,263,539 and 16,300,564 bp and distally between 15,763,401 and $15,768,918$ bp (Fig. 2). The microdeletion includes only two genes: AP1S2 and GRPR (Fig. 2).

The deletion was no detectable by array-CGH in the father. The healthy mother appeared carrier of the same imbalance as the child, while no skewed X-inactivation could be detected (data not shown).

\section{Discussion}

Only point mutations in the AP1S2 gene have so far been reported [6-8]. Altogether, three different nonsense mutations (c.154C > T, c.106C $>$ T and c.226G $>\mathrm{T}$ ) and three splice site mutations (c.180-5_180-1del4, c.288+5G > A and c.289-1G > C) have been identified in seven families [8], including three that have allowed the detection of a linkage to the AP1S2 region [11-14].

All of the previously described affected males have varying degrees of intellectual disability (from mild to profound) and their early lives were characterised by marked hypotonia; furthermore, most of them experienced delayed walking and speech development, language disturbances (from no language to minimal language), without any significant dysmorphic features. The patients for whom a radiological description is available also showed calcifications of the basal ganglia (see Borck et al. [8] for a detailed summary of the clinical features of patients harbouring AP1S2 mutations). The identified AP1S2 mutations co-segregating with the disease in the described families seem to underlie a specific and recognisable XLMR syndrome.

The clinical findings in our patient reflect most of those observed in the carriers of deleterious mutations: psychomotor retardation, a significant delay in walking and speech development, marked hypotonia in the first months of life that subsequently slightly improved, and unspecific dysmorphic facial features. A CT scan at the age of 4 months excluded the presence of cerebral calcifications, which is consistent with their reported delayed appearance in childhood [8].

As previously observed in unaffected female mutation carriers, the proband's mother, who is heterozygous for the AP1S2 deletion, shows random $\mathrm{X}$-inactivation and a normal phenotype, thus indicating that gene haploinsufficiency is insufficient to induce the pathological clinical features.

The GRPR gene (OMIM ID: 305670) close to AP1S2 is also deleted in the child (Fig. 2). This gene encodes the gastrin-releasing peptide receptor (GRPR), which regulates a broad spectrum of biological responses, acts as a growth factor in different types of human cancer, and has been implicated in the pathogenesis of mammalian neurological and psychiatric disorders, including the neurodevelopmental disorders associated with autism $[15,16]$.

In his early infancy, our patient showed hand stereotypies and poor social interactions, which are usually reported in patients with autistic spectrum disorders (ASD). However, it is hazardous to consider a correlation with the absence of this gene as the findings of a recent study of 149 Italian autistic patients do not indicate that GRPR plays a major role in ASD [17]. The stereotypies of our patient may therefore also be associated with the AP1S2 deletion because two of the described XLMR patients with stereotypies have been diagnosed as having ASD [8].

In conclusion, ours is the first description of a patient with syndromic MR and an AP1S2 deletion. The absence of AP1S2 leads to clinical features that overlap those associated with inactivating point mutations in males, thus confirming the involvement of this gene in a recognisable XLMR syndrome.

\section{References}

[1] H. Leonard, X. Wen, The epidemiology of mental retardation: challenges and opportunities in the new millennium, Ment. Retar. Dev. Disab. Res. Rev. 8 (2002) 117-134.

[2] H.H. Ropers, B.C. Hamel, X-linked mental retardation, Nat. Rev. Genet. 6 (2005) 46-57.

[3] P. Chiurazzi, C.E. Schwartz, J. Gecz, G. Neri, XLMR genes: update 2007, Eur. J. Hum. Genet. 16 (2008) 422-434.

[4] P.S. Tarpey, R. Smith, E. Pleasance, A. Whibley, S. Edkins, C. Hardy, S. O’Meara C. Latimer, E. Dicks, A. Menzies, P. Stephens, M. Blow, C. Greenman, Y. Xue, C. Tyler-Smith, D. Thompson, K. Gray, J. Andrews, S. Barthorpe, G. Buck, J. Cole, R. Dunmore, D. Jones, M. Maddison, T. Mironenko, R. Turner, K. Turrell, J. Varian, S. West, S. Widaa, P. Wray, J. Teague, A. Butler, A. Jenkinson, M. Jia, D. Richardson, R. Shepherd, R. Wooster, M.I. Tejada, F. Martinez, G. Carvill, R. Goliath, A.P.M. de Brouwer, H. van Bokhoven, H. Van Esch, J. Chelly, M. Raynaud, H.H. Ropers, F.E. Abidi, A.K. Srivastava, J. Cox, Y. Luo, U. Mallya, J. Moon, J. Parnau, S. Mohammed, J.L. Tolmie, C. Shoubridge, M. Corbett, A. Gardner, E. Haan, S. Rujirabanjerd, M. Shaw, L. Vandeleur, T. Fullston, D.F. Easton, J. Boyle, M. Partington, A. Hackett, M. Field, C. Skinner, R.E. Stevenson, M. Bobrow, G. Turner, C.E. Schwartz, J. Gecz, F.L. Raymond, P.A. Futreal, M.R. Stratton, A systematic, large-scale resequencing screen of $X$ chromosome coding exons in mental retardation, Nat. Genet. 41 (2009) 535-543.

[5] T. Kleefstra, B.C.J. Hamel, X-linked mental retardation: further lumping, splitting and emerging phenotypes, Clin. Genet. 67 (2005) 451-467.

[6] P.S. Tarpey, C. Stevens, J. Teague, S. Edkins, S. O'Meara, T. Avis, S. Barthorpe G. Buck, A. Butler, J. Cole, E. Dicks, K. Gray, K. Halliday, R. Harrison, K. Hills, J. Hinton, D. Jones, A. Menzies, T. Mironenko, J. Perry, K. Raine, D. Richardson, R. Shepherd, A. Small, C. Tofts, J. Varian, S. West, S. Widaa, A. Yates, R. Catford, J. Butler, U. Mallya, J. Moon, Y. Luo, H. Dorkins, D. Thompson, D.F. Easton, R. Wooster, M. Bobrow, N. Carpenter, R.J. Simensen, C.E. Schwartz, R.E. Stevenson, G. Turner, M. Partington, J. Gecz, M.R. Stratton, P.A. Futreal, F.L. Raymond, Mutations in the gene encoding the Sigma 2 subunit of the adaptor protein 1 complex, AP1S2, cause X-linked mental retardation, Am. J. Hum. Genet. 79 (2006) 1119-1124.

[7] Y. Saillour, G. Zanni, V. Des Portes, D. Heron, L. Guibaud, M.T. Iba-Zizen, J.L. Pedespan, K. Poirier, L. Castelneau, C. Julien, C. Franconnet, D.T. Bonthron, M.M. Porteous, J. Chelly, T. Bienvenu, Mutations in the AP1S2 gene encoding the sigma 2 subunit of the adaptor protein 1 complex are associated with syndromic X-linked mental retardation with hydrocephalus and calcifications in basal ganglia, J. Med. Genet. 44 (2007) 739-744.

[8] G. Borck, A. Mollà-Herman, N. Boddaert, F. Encha-Ravazi, A. Philippe, L. Robel, I. Desguerre, F. Brunelle, A. Benmerah, A. Munnich, L. Colleaux, Clinical, cellular, and neuropathological consequences of AP1S2 mutations: further 
delineation of a recognizable X-linked mental retardation syndrome, Hum. Mut 29 (2008) 966-974.

[9] N. Glyvuk, Y. Tsytsyura, C. Geumann, R. D’Hooge, J. Hüve, M. Kratzke, J. Baltes, D. Böning, J. Klingauf, P. Schu, AP-1/ $\sigma 1 \mathrm{~B}$-adaptin mediates endosomal synaptic vescicle recycling, learning and memory, EMBO J. 29 (2010) 1318-1330.

[10] R.C. Allen, H.Y. Zoghby, A.B. Mosely, H.M. Rosenblatt, J.W. Belmon, Methylation of HpaII and Hhal sites near the polymorphic CAG repeat in the human androgen-receptor gene correlates with $\mathrm{X}$ chromosome inactivation, Am. J. Hum. Genet. 51 (1992) 1229-1239.

[11] G. Turner, A. Gedeon, K. Bronwyn, R. Bennet, J. Mulley, M. Partington, Syndromic form of X-linked mental retardation with marked hypotonia in early life, severe mental handicap, and difficult adult behavior maps to Xp22, Am. J. Med. Genet. 117 (A) (2003) 245-250.

[12] N.J. Carpenter, W.T. Brown, Y. Qu, K.L. Keenan, Regional localization of a nonspecific X-linked mental retardation gene (MRX59) to Xp21.2-p22.2, Am. J. Med. Genet. 85 (1999) 266-270.
[13] K. Fried, X-linked mental retardation and/or hydrocephalus, Clin. Genet. 3 (1972) 258-263.

[14] K. Fried, R. Sanger, Possible linkage between Xg and a locus for a gene causing mental retardation with or without hydrocephalus, J.Med.Genet.10(1973)17-18.

[15] Y. Ishikawa-Brush, J.F. Bolton, A.P. Miller, F. Francis, H.F. Willard, H. Lehrach, A.P. Monaco, Autism and multiple exostoses associated with an X;8 translocation occurring within the GRPR gene and $3^{\prime}$ to the SDC2 gene, Hum. Mol. Genet. 6 (1997) 1241-1250.

[16] R. Roesler, J.A. Henriques, G. Schwartsmann, Gastrin-releasing peptide receptor as a molecular target for psychiatric and neurological disorders, CNS Neurol. Disord. Drug. Targets 5 (2006) 197-204.

[17] G. Seidita, M. Mirisola, R.P. D’Anna, A. Gallo, R.T. Jensen, S.A. Mantey, N. Gonzalez, M. Falco, M. Zingale, M. Elia, L. Cucina, V. Chiavetta, V. Romano, F. Cali, Analysis of the gastrin-releasing peptide receptor gene in Italian patients with autism spectrum disorders, Am. J. Med. Genet. B. Neuropsychiatr. Genet. 147B (2008) 807-813. 